\title{
PERCEPTIONS OF MARKETING \& DIGITAL TRANSFORMATION IN GREEK PUBLIC HIGHER EDUCATION ORGANIZATIONS IN THE CONTEXT OF DIGITAL DARWINISM
}

\author{
Nektarios S. Makrydakis* \\ University of the Aegean, Mytilene Greece \\ e-mail:nektarm@aegean.gr
}

Received June 20, 2021; accepted July 19, 2021; published July 28, 2021.

\begin{abstract}
Objective: Marketing and digital transformation in the public institutions of higher education in Greece, have key role in the context of the digital revolution. The study aimed at investigating the perceptions and views explicitly or implicitly of the management of Greek public universities regarding the need to adopt new practices such as marketing and its digital transformation and to find out the factors that shape perceptions. Research Design \& Methods: The study adopted a quantitative method conducting in-depth interviews with rectors and vice-rectors of 10 representative Greek Universities. Findings: Results indicated that administrators believe that marketing and its digital transformation have great impact in attracting students and that the duration of the operating time of a university is directly related to the formation of perceptions about marketing and digital transformation in the context of Digital Darwinism. Implications \& Recommendations: Universities will be able to understand the extent of their reaction to the adoption of new applications such as marketing. Contribution \& Value Added: The present study is primarily a useful tool for public university administrations in their efforts to adopt marketing practices to understand which areas to focus on in order to effectively implement marketing and its digital transformation. The study also provides them with the tools to easily recognize their degree of maturity in terms of their culture and perceptions towards the application of marketing practices. In addition the study enriches the literature on the management field of higher education institutions. It highlights factors such as the duration of operation, the geographical location and the size of a university compared to administrative practices.
\end{abstract}

Keywords: marketing strategy; digital transformation; public higher education organizations.

JEL codes: M31

Article type: research paper

\section{INTRODUCTION}

The purpose of this study is to identify and record the views and perceptions of the management of public Greek universities regarding the adoption of marketing practices and its digital transformation. In the international environment there were initially different views on the necessity of introducing marketing as an administrative function in universities, however it is now a common practice. In the Greek academic environment, the administrative function of marketing is absent and this study approach the perceptions of the universities' management regarding the specific issue as well as what factors influence the specific administrative perception. The main question of the study is «Which are the perceptions of Greek public universities towards the implementation and adoption of marketing and it's digital transformation?» 
Kotler \& Fox (2006) pointed out that several universities, in their attempt to keep up with the times, hired external advertisers, who treated the educational product like any other consumer product. Greek universities do not have marketing departments in their structure or flexible organizational culture because they follow the outdated and bureaucratic model of organizing the public sector and suffer from its bureaucratic perceptions and dysfunctions, as Featherstone (2015) has aptly described Greece as a societé bloquée 'due to the inherent systemic weaknesses of any public body: a multitude of cumbersome structures, fragmentation of responsibilities, inefficient management of human resources and resources, lack of objectives and coordination, Insufficient access to information are some of the elements that compose the Greek "administrative malpractice". All of the above contribute to the lack of knowledge of the value of marketing by public universities to deal with the rapidly evolving technological and non-technological environment.

In this context, the administrations of the Greek public universities are invited to crystallize their views on the need for marketing by higher education institutions and scientists are asked to answer the question of what are the real attitudes of public universities towards marketing and what factors influence them. One phenomenon that universities have to face is Digital Darwinism (Shailesh \& Priya, 2018) which, according to Kreutzer \& Land (2013) is defined as the phenomenon that threatens all rigid organizations and occurs when technology and society evolve faster than the pace adaptation of organizations. Without the operation of strategic marketing, it is considered very difficult to use digital development with a student-centered approach as a single structure. In the Greek public sector and especially in the public institutions of higher education there is a gap in the study of the implementation of their administrative marketing function. While other sciences have been studied and applied, marketing is underdeveloped in Greek public organizations (Rivero \& Theodore, 2013) such as public universities. The theory has a gap, a part of which the present study fills.

\section{LITERATURE REVIEW}

Many conservative academics believed that the value of education was so strong that it did not need a marketing department and no support to stimulate demand, stressing that universities should not be transformed from educational institutions into businesses or use television and other advertisements. because in this way education would use the same means as using a car or a soap to increase its demand, while proponents of marketing argued that the issue was not ethical but a matter of the survival of institutions and that marketing gives universities an important advantage in the difficult competitive environment they are called upon to operate (Pelletier, 1985). Already From the late 1970 s to the early 1980s, many university administrators and academics alike, especially in the Western world, embraced the idea of introducing marketing into higher education and began looking for marketing scientists to staff new marketing departments their universities (Smith \& Cavusgil, 1984). Burns, in 1988, in the Journal of Marketing for Higher Education, stressed that the purpose of higher education marketing is not to apply the principles of consumer product or service marketing and become a business but the university's marketing department must adapt all the elements of the marketing mix to the needs of the academic environment.

It is time for higher education institutions to create marketing departments and use strategic marketing planning techniques, with the necessary adjustments to their non-profit character, their social and cultural role and thus be able to better serve their students, sponsors. And the societies to which they belong and Kotler \& Fox (2006) point out that several universities, in their quest to keep up with the times, have recruited executives and external collaborators, who treated the educational product like any other consumer product Çetin (2004) agrees with the above conclusion.

A key problem for the application of marketing in public higher education organizations in Greece is the fact of the impact of an institutional system based on pluralism and the lack of technocratic administration. According to a study by the GSEE Labor Institute, a major problem is the plethora of often conflicting laws, the result of bureaucratic logic. The public university provides services to citizens but the decision to introduce a new function may require the time-consuming process of passing a law or a ministerial decision rather than a quick internal decision of the agency (Kotler \& Lee, 2006). 
The adoption of the marketing philosophy and culture by the educational public organizations requires the change of attitude for the way they are managed and operated as underlined by the Kotler \& Lee (2006), while according to The World University Ranking (2020), student engagement is digitally enhanced and in some cases necessitated by new circumstances and circumstances such as the spread of Covid-19 viruses, emphasizing the need for transfer of the marketing budget from traditional to digital, to increase the digital and virtual experience of prospective students and for continuous interaction on social media, which means that every university needs a strong marketing department. The need to adopt marketing and its digital version within universities has been highlighted by several researchers with the Maringe (2006) to emphasize that without the development of a marketing policy strategy, universities will continue to send different messages from their individual faculties and structures.

Hayes et al. (2009) studying the impact of social media as a marketing tool for a university found that there is a positive relationship between those who follow its social media pages and the likelihood of applying to study at it. Whitehead (2012) went one step further and emphasized that the internet and social media are vital tools for attracting students and McAlexander et al. (2005) added that they affect the overall public image of the university. The participation of most students and potential students, in social media has been further enhanced by the widespread use of portable electronic devices, which make access to them even more comfortable and enjoyable (Michaluk, 2008).

The prevailing culture in a university is often seen as a valuable strategic asset for marketing and the transformation and utilization of digital technologies (Downes \& Nunes, 2013), can also be a source of inaction that prevents change (Kummer \& Schmiedel, 2016).

Many universities lack marketing structures in order to develop the necessary marketing strategies to deal with competition more effectively (Molesworth et al., 2009) while the lack of marketing department does not allow higher education organizations to operate effectively in the online environment, applying digital marketing and in particular search engine marketing, social media marketing, online advertising, post marketing, etc. (Chaffey, 2018). Gobble (2018) characterizes digital transformation as the process of transforming every structure of the organization, its activities and processes, its capabilities and operating philosophy, in order to achieve the maximum possible transformation with an impact on society, while universities if they want to stay alive and survive, it is necessary to evolve in this direction and follow the same course as the torrent of digital spread.

Arora \& Sanni (2019) states that university digital marketing is about achieving marketing goals through the application of digital technologies and tools and adds that it includes managing the internet presence, such as websites, mobile applications and social networking pages, while HallamBerry (2018) emphasizes that with digital marketing, organizations can face reality, consistently analyze developments and changes imposed by digital giants such as Instagram and Google, and address in a targeted, modern and convincing way digital "language" of today and tomorrow's audience.

According to the position of Zulfikar et al. (2018) higher education has always been an area with a unique character in terms of organizational model, key processes and objectives compared to other areas. The value and impact of digitization has a different meaning for each university and usually depends on the legal and social environment in which it operates (Nguyen, 2018), but also on the perceptions that have been formed in each university.

Peruta \& Shields (2017) point out that the reasons why universities use Facebook and social media are to communicate with students and alumni, to promote university news, to promote academic work, to promote research, and to recruitment of academic staff, while the context of digital marketing strategy, as reported by Carnegie Dartlet (2020), most of the actions of any higher education organization are aimed at turning internet users into visitors of its websites, so the effort to optimize websites is a crucial process because the ranking in first places of the machines secures thousands of visitors to them. 
Pringle \& Fritz (2019) stressed that social media provides opportunities for organizations, such as universities, to gain a corporate presence by creating a website with enriched capabilities according to the needs of the industry to which they belong. The SEM process usually starts with SEO and ends with search engine ads, Google, Bing, Yahoo and the rest depending on the targeting of each university while according to Search Engine Land (2019), Paid Search is the process of placing ads on search engines with the aim of increasing the number of visitors to university websites. The adoption of such practices requires knowledge and rapid response of management.

Higher education video marketing is evolving as the most powerful digital projection tool because despite the rapid development of social media, blogs and mobile applications, video attracts students like no other platform (Lister, 2019). Straub (2019) notes that according to a report by the World Economic Forum 2019 and a McKinsey survey, by 2025 more than $30 \%$ of global economic activity will take place through digital platforms.

The important role of organizational culture in the process of digital transformation is mentioned by Vexler (2019), according to which there are some special features, with great importance, that shape the Digital Culture of organizations.

Zhao et al. (2020) point out that many universities view digital technology as a nuisance or a necessary evil that they cannot ignore and believe that they should integrate it into existing organizational culture rather than adapt to the new digital environment. While according to a report by the international company Pricewaterhouse Coopers (2018) many universities develop specific digital strategies and tactics, in response to the massive shift to new technology, but without having a vision of a continuous digital transformation.

Benavides et al. (2020) report that some governments, with their policies, are hindering the modernization and streamlining of university administrative processes, creating inelastic conditions that prevent the proper and rapid implementation of digital transformation, while others are legislation and regulations to encourage universities to digitally adapt their processes and services to new social requirements in order to remain competitive. The Greek public university operates within the institutional framework defined by central government decisions, legislation and ministerial decisions, which are sometimes slow to adapt to new digital conditions, which is an obstacle to the adoption of administrative practices that promote its digital transformation. And its individual functions, such as digital marketing.

As Rof et al. (2020) have pointed out, the digital transformation of the university is an evolutionary process, which affects and transforms all major areas of activity, teaching, research and administration and is determined by factors such as culture.

\section{METHODS}

To examine the research question «Which are the perceptions of Greek public universities towards the implementation and adoption of marketing and it's digital transformation?», qualitative research methodology was selected as the most appropriate. The choice of qualitative methodology was made due to the nature of the research, according to which priority is given and emphasis on the study of the ways in which the representatives of public universities perceive and interpret the operation of marketing. The phenomenon of lack of marketing function as part of the organizational structure requires the explanation and understanding of "which", a question which can be answered more effectively using the qualitative methodology (Silverman, 2001).

At the same time, the qualitative method of interviews helps to explore a new issue such as the adoption of marketing functions by the public university and the positive or negative attitudes towards it. This research considered that the qualitative method with interviews is more appropriate for the interviewees to approach a topic without having preconceived notions about the important variables, gradually leading to the formulation of an approach for explaining and interpreting research data as opposed to the quantitative method where the variables used are conceptually predetermined, while the results are a priori predictable from the framework of the theory. 


\section{Sampling Strategy}

The need to study in depth the views and perceptions of a representative sample of Greek public higher education organizations and within their appropriate representatives led me to the strategy of 'Criterion sampling'. This method was chosen in order to select those cases that will be the sample of the research according to two criteria a) the position of the respondent within the university and b) the representativeness of the university. In particular, regarding the first criterion, the appropriate sample includes exclusively people who have a key role in the public Greek university and participate in administrative decisions such as rectors and vice-rectors. The second criterion concerning representativeness was based on the assumption that a heterogeneous but at the same time representative sample would be needed.

According to the researchers Iosiphides \& Spyridakis (2006), qualitative research has no numerical limitations in terms of sample size which does not need to be quantitatively large. In this context, a representative sample size was selected, consisting of ten public institutions and a corresponding number of representatives, who meet the sampling criteria, from a total of twenty-four Greek public universities. The final size of the sample was not precisely determined from the beginning but emerged from the course of the interviews when it was found that the interviews did not contain new data in the production of useful conclusions because information and concepts that had already been mentioned began to be repeated.

In particular, the interviewees have the position of rector or vice-rector and are therefore in the highest possible hierarchical position within public universities. This ensured that their views reflected the culture and philosophy prevailing at the university and through their own answers the conclusions gained special weight. The interviews were attended by representatives of public universities, of which three are rectors and seven are vice-rectors (Table 1).

\section{Data Collection Techniques}

The technique chosen for data collection is the semi-structured interview. This technique was deemed the most appropriate to answer the research question because it can more easily reveal the conceptions of public university representatives about a virgin research area by providing open access (Flick, 2009).

\section{Design and Conduct Qualitative Interviews}

The questions were designed to be open, flexible and understandable by the respondents while at the same time I tried to be as relevant as possible to the experiences of the participants. I avoided questions that are too long, ambiguous or complex that may not be understood. All individual interviews were conducted via the electronic zoom application electronically, due to Covid19, and saved in video format, in mp4 format. The interviews took place in a relatively short period of time and in particular on the dates 1, 2, 4, 8, 12 February, 17, 31 March and 2, 5, 6 April 2021.

\section{Organization and Analysis of Qualitative Data - Coding}

The rules of notation were used to translate qualitative individual interviews into text (Silverman, 2001) and a series of conventions were used to capture all forms of communication and interaction, such as the duration of silence, the pasting of utterances, the indication of a accent through the volume and / or volume of the voice, the accent nuances within a word, the abrupt changes in the volume of the voice, a part of pronunciation that is pronounced faster or slower than the rest of the pronunciation, etc., which are not could otherwise be included in a transliteration of spoken word into text.

For the organization of the material, the process of coding was followed, ie the division of the material into individual sections based on a common system of codes. Thematic analysis is the most appropriate method to identify and understand the themes within a data set and thus to have cognitive access to semantics and experiences. Regarding the way in which utilized the process of thematic analysis and in particular the coding of the theoretical categories, is being chosen a mixed process with the abductive and the deductive method. 
Table 1. Sample of Research

\begin{tabular}{|c|c|c|}
\hline Institution & $\begin{array}{c}\text { Position of } \\
\text { Interviewees }\end{array}$ & Criterion \\
\hline $\begin{array}{l}\text { National Technical } \\
\text { University of Athens }\end{array}$ & Vice-Rector & $\begin{array}{l}\text { Is the most representative large public institution, located } \\
\text { in the capital and has the reputation of the leading and most } \\
\text { recognizable Greek institution. }\end{array}$ \\
\hline $\begin{array}{l}\text { University of the } \\
\text { Aegean }\end{array}$ & Vice-Rector & $\begin{array}{l}\text { Is a medium-sized a critic university, has the unique feature } \\
\text { of operating in the largest number of different geographical } \\
\text { locations and especially in } 6 \text { islands of the Aegean Sea. } \\
\text { Is one of the newest universities in Greece founded in }\end{array}$ \\
\hline $\begin{array}{l}\text { University of } \\
\text { Western Macedonia }\end{array}$ & Vice-Rector & $\begin{array}{l}\text { 2003. In } 2019 \text { the University of Western Macedonia } \\
\text { merged with the Technological Institute of Western } \\
\text { Macedonia and has facilities in } 5 \text { cities in the Region of } \\
\text { Western Macedonia. }\end{array}$ \\
\hline Ionian University & Rector & Is one of the smallest universities in the country. \\
\hline $\begin{array}{l}\text { Hellenic Open } \\
\text { University }\end{array}$ & Rector & $\begin{array}{l}\text { Is a unique case among public universities due to the fact } \\
\text { that its mission is exclusively the provision of distance } \\
\text { undergraduate and postgraduate education and training. }\end{array}$ \\
\hline University of Patras & Vice-Rector & $\begin{array}{l}\text { Based in Patras, is the largest university in western Greece } \\
\text { and one of the largest in the country while in } 2013 \text { it joined } \\
\text { the University of Western Greece and in } 2019 \text { joined the } \\
\text { Technological Educational Institute of Western Greece } \\
\text { (TEI of Western Greece). }\end{array}$ \\
\hline $\begin{array}{l}\text { University of West } \\
\text { Attica }\end{array}$ & Rector & $\begin{array}{l}\text { Is the third largest university in the country in number of } \\
\text { enrolled undergraduate students and its establishment in } \\
2018 \text { came through the process of merging the TEI of } \\
\text { Athens and the University of Piraeus Technological Sector, } \\
\text { while in } 2019 \text { the National School of Public Health joined. }\end{array}$ \\
\hline $\begin{array}{l}\text { Athens University of } \\
\text { Economics and } \\
\text { Business }\end{array}$ & Vice-Rector & $\begin{array}{l}\text { Operates in Athens from dates back to 1903, with studies } \\
\text { exclusively in economics and administration. }\end{array}$ \\
\hline Panteion University & Vice-Rector & $\begin{array}{l}\text { A university of Social and Political Sciences based in } \\
\text { Athens, it is one of the most famous universities in Greece. }\end{array}$ \\
\hline University of Crete & Vice-Rector & $\begin{array}{l}\text { A university with forty years of operation on the largest } \\
\text { island of Greece. }\end{array}$ \\
\hline
\end{tabular}

\section{FINDING}

The coding about marketing department necessity (Table 2) gave the following codes from which the theme "Is considered necessary to create a marketing department in the Greek public university" emerged. The following table shows the codes formed by the perceptions of interviewees about the necessity of marketing department and then excerpts from the interviews are presented.

From the point of view of the vice-rector 3, there was a detailed thought in favor of creating a department or marketing department within the university with permanent staff, which reveals the need to implement this change which is strongly supported.

Respectively, the rector 2 advocates the creation of a special marketing structure within the university which must choose the study programs. A finding is also based on the views of Vice Rector 2, who states that while he considers that there is a need for the implementation of marketing by the public university, he reveals that he has not considered the creation of a department or marketing department at the public university but finds it quite interesting idea.

Vice Rector 5 emphasizes that today marketing is done by the public relations department while the work of the department is different and considers that both marketing and public relations should be part of a wider management. Perceptions also agree with the above of Vice Rector 3, who states that the lack of a marketing department has turned the university to collaborating with external partners and others who may have at least an indirect connection to the field of marketing. 
Rector 1 also has a positive attitude towards the creation of a marketing department and justifies it with the unified identity and image that a university should project, which is difficult to happen when non-specialists, different people and schools are involved, without following a specific strategy.

Table 2. Perceptions on Creating a Marketing Department

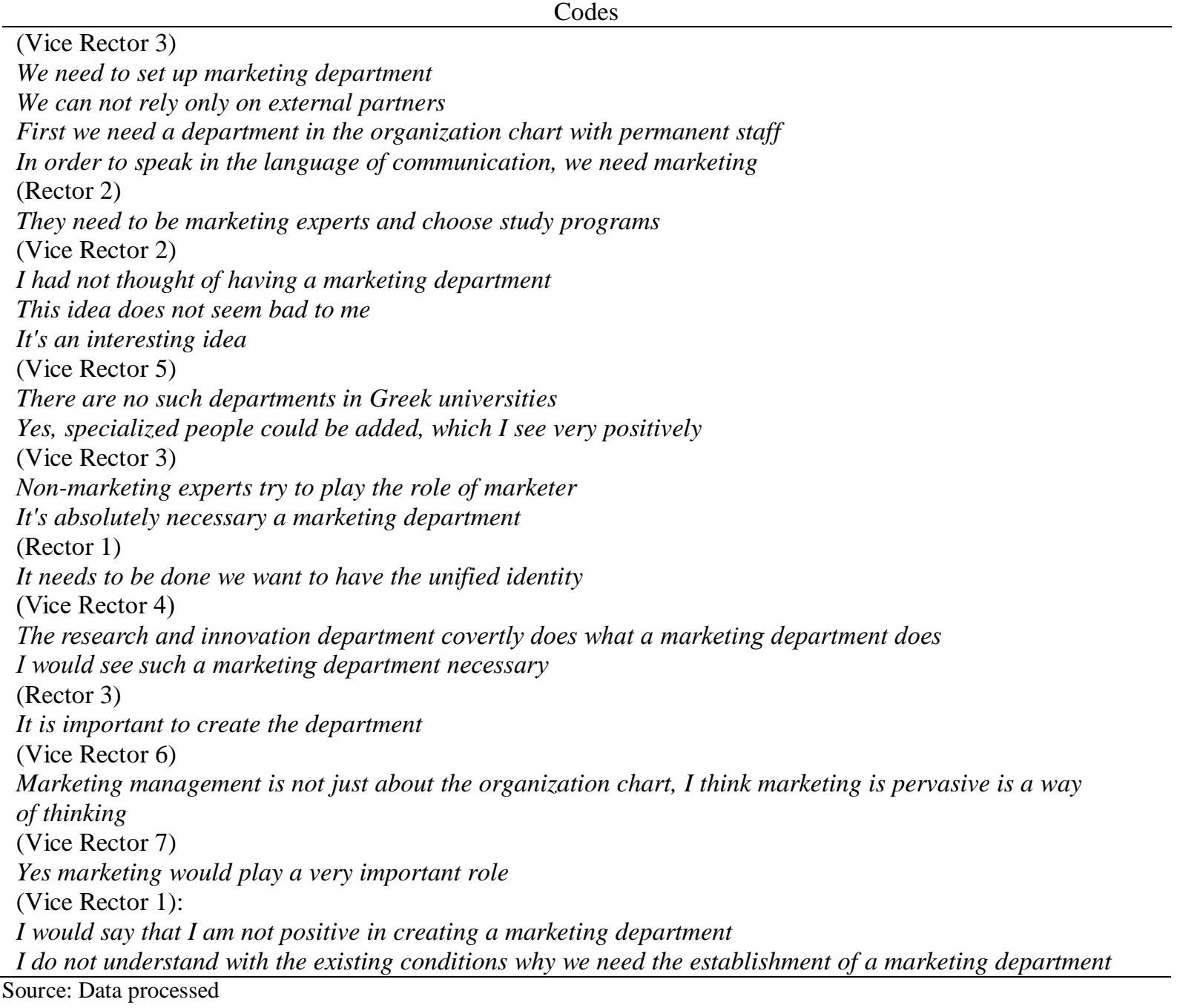

Vice Rector 4 also considers it necessary to create a marketing department because it reveals that part of the marketing functions are necessarily done by another department and even states that this is done "covertly". The importance of having a marketing department but with specialized employees is raised by the rector 3 who means that it is useless to create a department and place people who do not really know the subject. Therefore, not only the necessity of having a department is emphasized, but also its perfect staffing.

The perception of Vice Rector 6 puts marketing in the role it really should be, that is, not only as a marketing director but also as a philosophy that must go through all employees in order to satisfy students, while Vice Rector 7 believes that marketing can to play a very important role.

There is also one and only different view from Vice Rector 1, in the perception of a representative of the administration of Greek universities, and it seems that they treat marketing as something that can be a threat to the established situations that they may wish to maintain and thus fail to see its benefits.

The codification (Table 3) concerning organizational culture reflected in the next table and the theme formed by the codes is «The culture does not allow the public university to follow Digital Darwinism». The following table shows the codes formed by the perceptions of interviewees about the culture of organization and then excerpts from the interviews are presented. 
Table 3. Perceptions for Organizational Culture

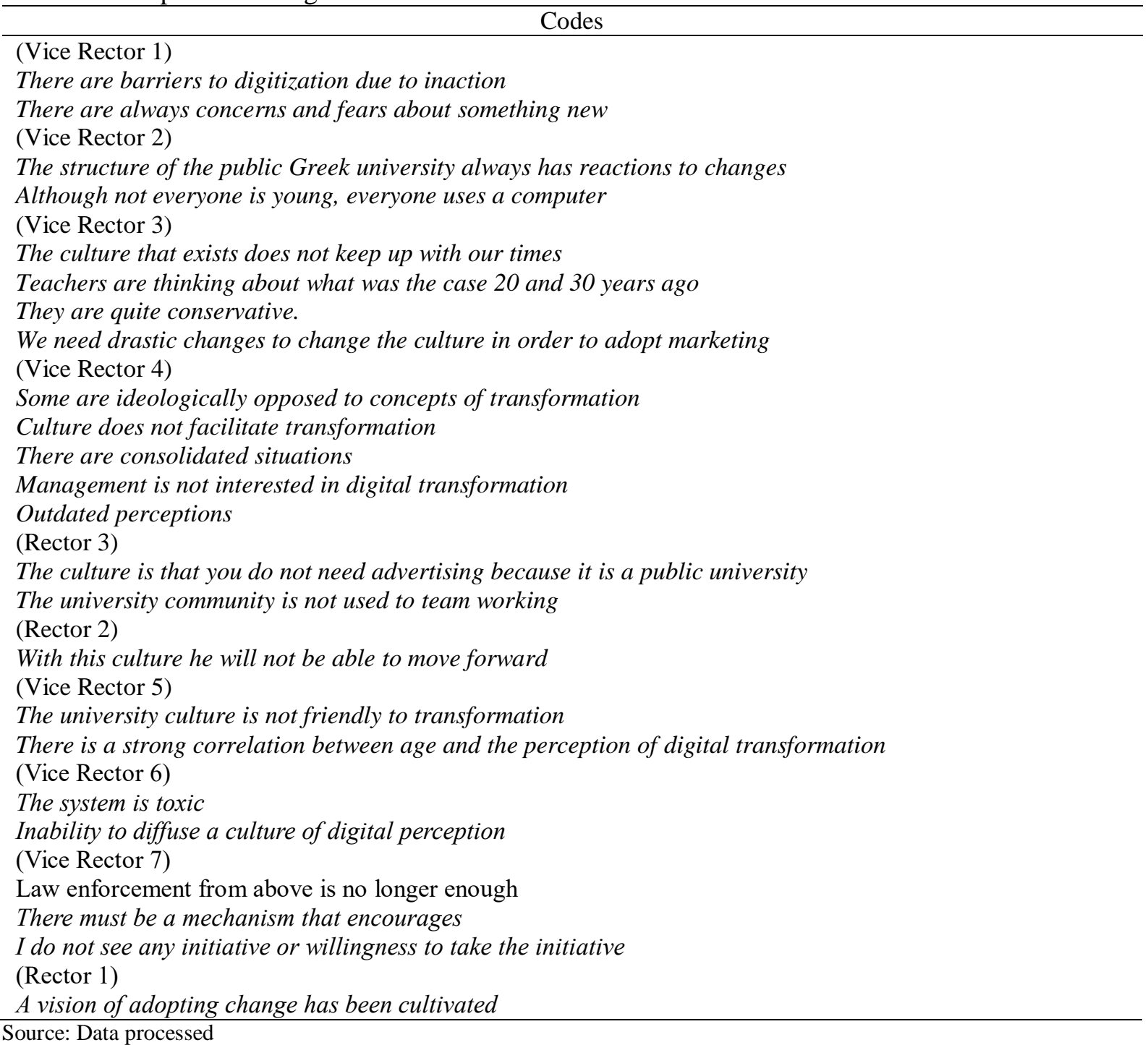

The resistance from the internal environment of the university as well as the fear for the new is emphasized by the vice-rector 1 as cultural factors that do not facilitate the quick adaptation to the digitization while the vice-rector 2 believes that there are always reactions in universities to changes and therefore there is no culture of direct adaptation but digitization and any adaptation will be done but in a way as a forced change.

In addition, Vice Rector 3 clearly states that the culture in the Greek public university does not keep pace with the times which complete the puzzle of the findings regarding the theory of Digital Darwinism, showing culture as a decisive obstacle in adapting to changing conditions.

The phenomenon of negative culture in anything new, such as marketing, that may have been applied, first, in the private sector, emphasizes, the rector 3. He typically states that because the university is public some academics and officials believe that there is no need for advertising.

Rector 2 noted that current culture is outdated but with the change of generation and if marketing is implemented from the beginning, it can be adopted with a positive sign. Vice rector 5 also states that the university culture does not fully serve the digital transformation, so it is characterized as mixed in the sense that the administration is looking for those willing employees who embrace the digital transformation who are mainly young and older can not meet.

Another interesting finding came from the views of Vice Rector 2 who largely believes that the existence of a culture of adaptation to digital and non-changing conditions is mainly about specific 
actions and not so much the holistic approach of a long-term philosophy of rapid perception of change and activation of customization procedures.

Rector 1, although he has referred to difficulties arising from the institutional framework, nevertheless believes that in some universities there is the flexibility for rapid change and they try to cultivate a culture of change. In addition, Vice Rector 4 believes that perhaps the newer universities have a more flexible culture, while they believe that the current culture in universities does not allow digital transformation, especially when it comes to large and therefore rigid universities, also if they have theoretical studies accompanied by more and by the mood and skills of management.

Finally, Vice-rector 6 characterizes the operating system of public universities as completely inaccessible to the diffusion of digital culture, while Vice-Rector 7 considers that a new motivated mechanism is needed, law enforcement is not enough, so that there is a disposition for initiative and adaptation.

The coding (Table 4) that concerns digital transformation of marketing is reflected in the next table and the topic formed by the codes is «Digital marketing is considered very important for attracting students and especially the new generation». The following table shows the codes formed by the perceptions of interviewees about the role of digital transformation of marketing and then excerpts from the interviews are presented.

Table 4. Perceptions About Digital Transformation of Marketing

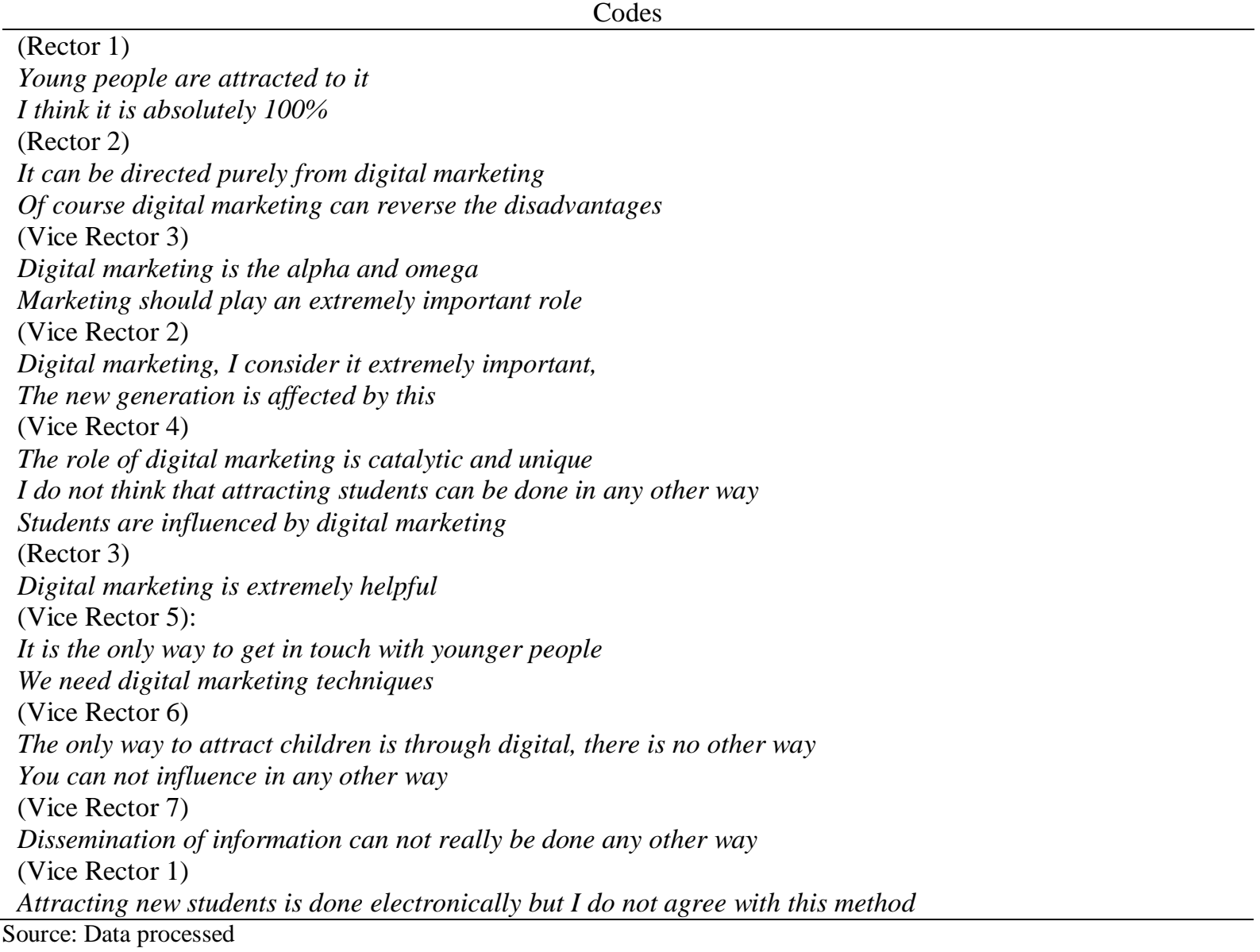

Rector 1 gives a dimension that reveals that he believes that digital marketing plays an important role in attracting students and focuses on the role that this can play in the new prospective student's initial contact with the university's digital applications.

Vice Rector 4, after expressing the view that the role of digital marketing strategy is a catalyst for attracting students, adds that it is the only way in which the university can influence the current new generation of potential students. 
An interesting finding emerges from the views of Rector 2 who believes that those who know well what they want to study, as he typically says those who have a "passion" for a science are not influenced by digital marketing, but there are many who do not know or do not have decide on the university or subject of study that the university can attract through digital marketing.

Vice rector 3 is an ardent supporter of digital marketing, expressing the view that it is the alpha and omega for a university and that it has a great deal of importance in the process of attracting students. Also, although he believes that geographical criteria play an important role in choosing a university, he does not diminish the value of digital marketing in attracting students, but rather reinforces it, saying that it plays an important role among similar universities that compete to attract students from the same university.

The geographical criterion seems to be of great concern to the administrations of the regional universities with Vice Rector 2 showing that he understands the potential of digital marketing to attract young people. Rector 2 also believes that there are geographical criteria but digital marketing can add differentiation between "homogenized departments".

Rector 3 adds that digital marketing is very important in attracting the new generation which uses and is influenced more by each of the smartphones and especially through this the university can attract quality students.

Vice Rector 5 says that the only way for the university to get in touch with the new generation is through digital marketing applications, which are even more necessary when the university wants to address young and non-students from abroad who may be have not listened to the university, while it is extremely necessary in times like that of the Covid 19 pandemic.

Vice rector 6 also believes that there is no other way for the university to attract and influence the new generation other than the use of digital marketing while the university does not exist if it does not exist digitally. Vice Rector 7 has the same perception, adding that digital marketing tools affect not only the younger generation but also the older ones who want to be educated.

Vice Rector 1 states that digital marketing is implemented by Anglo-Saxon universities and is not suitable in Greece for attracting students from public higher education institutions and then accepts that attracting new students is done electronically and that all universities in Greece have on all social media. There is an internal contradiction, which is attributed to superficial or limited knowledge of the subject of marketing, to entrenched beliefs that identify each new practice with an attempt at privatization.

After grouping and separating the answers of the interviewees by thematic area, then from the analysis of the words of each interviewee recording exactly what he said, from interpretation of what have said and from the general perception that I understood during the interviews, finally the perceptions emerged and the total attitude of each respondent shaped whose reflects the culture of the university it represents.

For example, from what Vice-Rector-1 said was found that he has an almost negative perception towards marketing and its digital transformation (among others Vice-Rector-1 said):

«I would say that I am not positive in creating a marketing department»,

«I do not understand with the existing conditions why we need the establishment of a marketing department»,

«There are always concerns and fears about something new»,

«Attracting new students is done electronically but I do not agree with this method».

On the contrary Vice-Rector-3 has a strongly positive perception (among others Vice-Rector-3 said):

«Digital marketing is the alpha and omega»

«Marketing should play an extremely important role»

JMER, 2021, 02(1), 57-73 
«We need drastic changes to change the culture in order to adopt marketing»

«We need to set up marketing department»

«We can not rely only on external partners»

«First we need a department in the organization chart with permanent staff»

«In order to speak in the language of communication, we need marketing»

Respectively, the perceptions of all others respondents were formed, and Table 5 was completed, which presents the prevailing perceptions towards marketing that prevail in each public educational organization.

Table 5. Perceptions towards Marketing and it's Digital Transformation

\begin{tabular}{lc}
\multicolumn{1}{c}{ Institution } & Perceptions towards Marketing \\
\hline National Technical University of Athens & Almost negative \\
University of the Aegean & Positive \\
University of Western Macedonia & Strongly positive \\
Ionian University & Strongly positive \\
Hellenic Open University & Strongly positive \\
University of Patras & Positive \\
University of West Attica & Strongly positive \\
Athens University of Economics and Business & Moderately positive \\
Panteion University & Moderately positive \\
University of Crete & Positive \\
\hline
\end{tabular}

Source: Data processed

From the analysis of the qualitative research interviews, findings emerged which were not in the original design based on the research questions but are undoubtedly important elements that lead to additional important conclusions. During the analysis of the interviews, going further, it was found that there are new correlations between the perceptions that have been formed in the universities regarding the application of marketing and criteria such as the duration of operation of the higher education institution, its size and geographical location.

\section{DISCUSSION}

\section{The Criterion of the Duration of Operation of a Public University and the Perceptions Towards Marketing}

Table 6. Duration of Operation and Perception towards Marketing

\begin{tabular}{|c|c|c|c|}
\hline University & $\begin{array}{c}\text { Year of } \\
\text { Establishment }{ }^{1}\end{array}$ & $\begin{array}{l}\text { Perceptions towards } \\
\text { Marketing }\end{array}$ & Groups \\
\hline National Technical University of Athens & 1837 & Almost negative & \multirow{3}{*}{$\begin{array}{c}\text { Little } \\
\text { positive }\end{array}$} \\
\hline Athens University of Economics and Business & 1920 & Moderately positive & \\
\hline Panteion University & 1930 & Moderately positive & \\
\hline University of Patras & 1964 & Positive & \multirow{3}{*}{ Positive } \\
\hline University of Crete & 1973 & Positive & \\
\hline University of the Aegean & 1984 & Positive & \\
\hline Ionian University & 1984 & Strongly positive & \multirow{4}{*}{$\begin{array}{c}\text { Very } \\
\text { positive }\end{array}$} \\
\hline Hellenic Open University & 1992 & Strongly positive & \\
\hline University of Western Macedonia & 2003 & Strongly positive & \\
\hline University of West Attica & 2018 & Strongly positive & \\
\hline
\end{tabular}

Source: Data processed

Note: ${ }^{1}$ Data were taken from published data https://el.wikipedia.org/wiki/.

In order to confirm the above findings (Table 6), the behavior of two representative educational institutions regarding the frequency of organic ${ }^{2}$ posts on popular social media studies. Social media as the core of social media marketing reflects the attitudes and culture towards marketing. 
Perceptions towards marketing and differentiation with the number of content posts on social media (Table 7).

Table 7. Perceptions towards Marketing and Number of Posts on Social Media (Period 1/2/2021 $6 / 4 / 2021)^{3}$

\begin{tabular}{cccccc}
\hline University & $\begin{array}{c}\text { Year of } \\
\text { Establishment }\end{array}$ & $\begin{array}{c}\text { Perceptions } \\
\text { towards } \\
\text { Marketing }\end{array}$ & $\begin{array}{c}\text { Twitter } \\
\text { (Number of } \\
\text { Posts) }\end{array}$ & $\begin{array}{c}\text { Facebook } \\
\text { (Number of } \\
\text { Posts) }\end{array}$ & $\begin{array}{c}\text { Instagram } \\
\text { (Number of } \\
\text { Posts) }\end{array}$ \\
\hline $\begin{array}{c}\text { National Technical } \\
\text { University of Athens }\end{array}$ & 1837 & Almost negative & 5 & 14 & 0 \\
$\begin{array}{c}\text { University of } \\
\text { Western Macedonia }\end{array}$ & 2003 & Strongly positive & 59 & 57 & 20 \\
\hline
\end{tabular}

Source: Data processed

Note: ${ }^{2}$ Non paid posts. ${ }^{3}$ https://twitter.com/ntua, https://twitter.com/uowm, https://www.instagram.com/ntua_unofficial/ , https://www.instagram.com/uowmgr/, https://www.facebook.com/uowm.gr,

https://www.facebook.com/NationalTechnicalUniversityofAthens/

Perceptions towards marketing and differentiation based on SEO (search engine optimization) actions of website optimization (Table 8). An important pillar of digital marketing is the process of SEO (search engine optimization), ie the process followed by an organization in order to optimize the ranking of their website in search engines. One of the most critical factors is the time spent by the average user when visiting the website. The more time it devotes to a website, the more it is considered to be satisfactory and useful to the user and therefore gets better search engine rankings. If an institution follows optimization rules, it means that it applies digital marketing practices more faithfully.

Table 8. Average time of users 'visits to the institutions' websites ${ }^{4}$

\begin{tabular}{lcccc}
\multicolumn{1}{c}{ University } & $\begin{array}{c}\text { Year of } \\
\text { Establishment }\end{array}$ & $\begin{array}{c}\text { Perceptions towards } \\
\text { Marketing }\end{array}$ & $\begin{array}{c}\text { Average Duration } \\
\text { of Visit per User on } \\
\text { the Institution's } \\
\text { Website }\end{array}$ & $\begin{array}{c}\text { Average } \\
\text { Group }\end{array}$ \\
\hline $\begin{array}{l}\text { National Technical University } \\
\text { of Athens }\end{array}$ & 1837 & Almost negative & $5: 00$ p.m. \\
$\begin{array}{l}\text { Athens University of } \\
\text { Economics and Business }\end{array}$ & 1920 & Moderately positive & $5: 04$ \\
$\begin{array}{l}\text { Panteion University } \\
\text { University of Patras }\end{array}$ & 1930 & Moderately positive & $4: 23$ \\
University of Crete & 1964 & Positive & $7: 08$ \\
University of the Aegean & 1973 & Positive & $7: 10$ \\
Ionian University & 1984 & Positive & $7: 35$ \\
$\begin{array}{l}\text { Hellenic Open University } \\
\text { University of Western }\end{array}$ & 1984 & Strongly positive & $7: 01$ \\
Macedonia & 1992 & Strongly positive & $7: 10$ \\
University of West Attica & 2003 & Strongly positive & $14: 50$ \\
\hline Source: Dataprocessed & 2018 & Strongly positive & $7: 07$ \\
\hline
\end{tabular}

Source: Data processed

Note: ${ }^{4}$ https://www.alexa.com/ digital marketing application which belongs to the company Amazon. Daily Pageviews per Visitor. Date of statistical control 12.6.2021. Estimates are based on traffic patterns across millions of web users throughout the world, and use data normalization to correct for biases.

Another factor is the average number of pages visited per user on the institution's website. The more pages a user visits on a website, the more it is also considered to be more satisfactory and useful to the user and therefore gets better search engine rankings and therefore in this case an institution follows optimization rules means that it implements more faithfully digital marketing practices (Table 9).

The term Bounce Rate refers to the rate of abandonment of a website by visitors, ie after their visit to the website they do not go to a second page but leave it. The lower this percentage, the more 
optimized the website is considered because it attracts and addresses the right audience, has interesting content and this is the result of inbound marketing actions (Table 10).

Table 9. Average number of pages visited per user on the institutions' websites

\begin{tabular}{lcccc}
\hline \multicolumn{1}{c}{ University } & $\begin{array}{c}\text { Year of } \\
\text { Establishment }\end{array}$ & $\begin{array}{c}\text { Perceptions towards } \\
\text { Marketing }\end{array}$ & Pageviews & $\begin{array}{c}\text { Average } \\
\text { Group }\end{array}$ \\
\hline $\begin{array}{l}\text { National Technical University } \\
\text { of Athens }\end{array}$ & 1837 & Almost negative & 5.1 & \\
$\begin{array}{l}\text { Athens University of } \\
\text { Economics and Business }\end{array}$ & 1920 & Moderately positive & 4.2 & 4.8 \\
$\begin{array}{l}\text { Panteion University } \\
\text { University of Patras }\end{array}$ & 1930 & Moderately positive & 5.5 & \\
University of Crete & 1964 & Positive & 5.3 & 5.2 \\
University of the Aegean & 1973 & Positive & 4.1 & \\
Ionian University & 1984 & Positive & 6.2 & \\
Hellenic Open University & 1984 & Strongly positive & 5.4 & 6.6 \\
University of Western & 1992 & Strongly positive & 6.2 & \\
Macedonia & 2003 & Strongly positive & 8.4 & \\
University of West Attica & 2018 & Strongly positive & 6.4 & \\
\hline
\end{tabular}

Source: Data processed

Note: ${ }^{5}$ Average number of pages visited per user on the institution's website

Table 10. Bounce rate of institutions' websites ${ }^{6}$

\begin{tabular}{lcccc}
\hline \multicolumn{1}{c}{ University } & $\begin{array}{c}\text { Year of } \\
\text { Establishment }\end{array}$ & $\begin{array}{c}\text { Perceptions towards } \\
\text { Marketing }\end{array}$ & $\begin{array}{c}\text { Bounce Rate } \\
\text { Website } \\
\text { Abandonment Rate }\end{array}$ & $\begin{array}{c}\text { Average } \\
\text { Group }\end{array}$ \\
\hline $\begin{array}{l}\text { National Technical } \\
\text { University of Athens }\end{array}$ & 1837 & Almost negative & $33.4 \%$ & \\
Athens University of & 1920 & Moderately positive & $34.8 \%$ & $34.8 \%$ \\
Economics and Business & 1930 & Moderately positive & $36.2 \%$ & \\
Panteion University & 1964 & Positive & $35.5 \%$ & \\
University of Patras & 1973 & Positive & $40.2 \%$ & $34.2 \%$ \\
University of Crete & 1984 & Positive & $27 \%$ & \\
University of the Aegean & 1984 & Strongly positive & $20 \%$ & \\
Ionian University & 1992 & Strongly positive & $16.7 \%$ & $23.7 \%$ \\
Hellenic Open University & 2003 & Strongly positive & $28.8 \%$ & \\
University of Western & & & & \\
Macedonia & 2018 & Strongly positive & $29.3 \%$ & \\
University of West Attica & & & & \\
\hline
\end{tabular}

Source: Data processed

Note: ${ }^{6} \mathrm{https}: / / \mathrm{www} . a \mathrm{lexa} . \mathrm{com} /$ digital marketing application which belongs to the company Amazon.

It is found that there is an absolutely positive relationship between the recent establishment and operation of a university with its attitude towards the adoption of marketing, that is, the younger a university is, the more positive it is in adopting its marketing strategy and digital transformation and vice versa. the more cautious.

\section{The Criterion of the Size of a Public University and Its Perception towards Marketing}

An attempt was made to determine whether there is a correlation between the size of the Greek public university and the perceptions of universities towards digital and traditional marketing (Tables 11, $12^{7}$ ). Universities were initially categorized into small and large but also into small, medium and large for even greater analysis.

Is found that there is a relatively positive relationship between the large size of a university and its attitude towards the adoption of marketing. that is, there is no positive relationship between smaller and medium-sized universities with an absolute attitude towards marketing. 
Table 11. Grouping of universities in 2 group sizes

\begin{tabular}{lccc}
\hline \multicolumn{1}{c}{ University } & $\begin{array}{c}\text { Size (number of } \\
\text { students) }\end{array}$ & $\begin{array}{c}\text { Perceptions towards } \\
\text { Marketing }\end{array}$ & Groups \\
\hline University of West Attica & 61,574 & Strongly positive & Large \\
Hellenic Open University & 42,000 & Strongly positive & (More than 26,000 \\
University of Western Macedonia & 36,500 & Strongly positive & students) \\
University of Patras & 33,940 & Positive & \\
University of Crete & 21,368 & Positive & \\
Panteion University & 20,000 & Moderately positive & Small \\
University of the Aegean & 15,000 & Positive & (Less than 26,000 \\
National Technical University of Athens & 13,000 & Almost negative & students) \\
Athens University of Economics and & 12,000 & Moderately positive & \\
Business & 8,000 & Strongly positive & \\
Ionian University & & & \\
Sont & & &
\end{tabular}

Source: Data processed

Note: ${ }^{7}$ Data were taken from published data https://el.wikipedia.org/wiki/.

Table 12. Grouping of universities in 3 group sizes

\begin{tabular}{lccc}
\hline \multicolumn{1}{c}{ University } & $\begin{array}{c}\text { Size (number of } \\
\text { students) }\end{array}$ & $\begin{array}{c}\text { Perceptions towards } \\
\text { Marketing }\end{array}$ & Groups \\
\hline University of West Attica & 61,574 & Strongly positive & Large \\
Hellenic Open University & 42,000 & Strongly positive & (More than 35,716 \\
University of Western Macedonia & 36,500 & Strongly positive & students) \\
University of Patras & 33,940 & Positive & Medium \\
University of Crete & 21,368 & Positive & $(17,587-35,716$ \\
Panteion University & 20,000 & Moderately positive & students) \\
University of the Aegean & 15,000 & Positive & Small \\
National Technical University of Athens & 13,000 & Almost negative & (up to 17,587 \\
Athens University of Economics and & 12,000 & Moderately positive & students) \\
Business & 8,000 & Strongly positive & \\
Ionian University & & &
\end{tabular}

Source: Data processed

\section{The Criterion of the Geographical Location of a Public University and the Perceptions towards Marketing}

The interviews showed a separation in those universities that operate and have their headquarters in a large city and in those located in the province (Table 13).

Table 13. Grouping of universities by geographical location ${ }^{8}$

\begin{tabular}{|c|c|c|c|}
\hline University & $\begin{array}{l}\text { Geographic } \\
\text { location }\end{array}$ & $\begin{array}{l}\text { Perception towards } \\
\text { Marketing }\end{array}$ & $\begin{array}{l}\text { Geographical } \\
\text { location groups }\end{array}$ \\
\hline University of West Attica & City Urban & Strongly positive & \multirow{5}{*}{ Urban } \\
\hline University of Patras & City Urban & Positive & \\
\hline Panteion University & City Urban & Moderately positive & \\
\hline National Technical University of Athens & City Urban & Almost negative & \\
\hline $\begin{array}{l}\text { Athens University of Economics and } \\
\text { Business }\end{array}$ & City Urban & Moderately positive & \\
\hline Hellenic Open University & Rural Region & Strongly positive & \multirow{5}{*}{ Rural } \\
\hline University of Western Macedonia & Rural Region & Strongly positive & \\
\hline University of Crete & Rural Region & Positive & \\
\hline University of the Aegean & Rural Region & Positive & \\
\hline Ionian University & Rural Region & Strongly positive & \\
\hline
\end{tabular}

Source: Data processed

Note: ${ }^{8}$ Data were taken from published data https://el.wikipedia.org/wiki/.

There is no positive relationship between the location criterion of a university and its attitude towards marketing adoption, however there seems to be a more positive relationship between location and operation in the region and the need to adopt its marketing strategy and digital transformation. 
Collectively we could find that the conditions regarding the need to create a marketing department at the Greek public university have begun to mature. The administrations of Greek public universities have begun to look for ways to deal with the ever-increasing competition, which is particularly felt in the online environment and the vast majority have now realized this need to implement a unified marketing strategy by specialized staff to adapt to rapidly changing conditions.

The amateur use of certain marketing applications by universities or the outsourcing of some services to external partners has not brought the desired results and the creation of marketing departments with specialized executives for the first time is recorded as necessary for Greek public universities.

However, there are ratings even between the positive perceptions, but there are also some individual voices which due to entanglements could be considered almost negative. There is a positive relationship between the recent establishment and operation of a university and its attitude towards the adoption of marketing, that is, the newer university is more positive it is in adopting marketing strategy and digital transformation, and vice versa, the older the wary.

There is a relatively positive relationship between the large size of a university and its perception towards the adoption of marketing, that is, the larger a Greek public university is, the more positive it is in the adoption of its marketing strategy and digital transformation, but the opposite does not apply. There is no positive relationship between smaller and medium sized universities with an absolute perception towards marketing.

Finally, there is no positive relationship between the criterion of a university's geographical location and its perception towards marketing adoption, however there seems to be a more positive relationship between location and operation in the province and the need to adopt a marketing strategy and digital transformation.

\section{CONCLUSION}

It is clear that digital marketing is understood by all those involved in the administration of the Greek public university that today can attract especially young students preparing to graduate from high school and is the largest target group of the university public. Also administration perceptions is that digital marketing has a key role in influencing and attracting students.

Although public universities use some marketing applications such as social media marketing there is a strong need to implement digital marketing in a professional way. Administration has been convinced that they need digital marketing applications but they also do not have the appropriate tools to implement it. In particular they use social media marketing in a no professional way and they do not apply search engine marketing to optimize their websites in the ranking of Google and other search engines.

Most Greek universities lack marketing strategy and the general digital strategy under the umbrella of which all the above digital applications operate in a coordinated, efficient and effective manner. The vision of the management team and the skills of the staff are issues that must be addressed by the universities and a condition for all the departments and functions of the university to commit to function as a well-tuned machine for the successful design and mainly implementation of the digital transformation. The results of the study could implement on any Greek public university so as to find out its perception and culture to develop the functions of marketing, in a more organized and structured way in order to be able to utilize its various benefits.

The study is useful for public university administrations in their efforts to implement marketing practices to understand which areas to focus on in order to effectively implement digital transformation as well. The study also provides them with the tools to easily recognize their degree of maturity in terms of their culture and perceptions towards the application of marketing practices.

The present study enriches the literature on the management field of higher education institutions. It highlights factors such as the duration of operation, the geographical location and the size of a university on the context of management theories.

JMER, 2021, 02(1), 57-73 
The field of research that future studies could focus on is the procedures and the way that should be followed by public universities in order to be able to adopt and implement digital marketing effectively overcoming institutional difficulties. The present study was limited to the research of the views and perceptions of the top management of the Greek public university organizations and specifically of the rectors and vice-rectors but the implementation of each new administrative procedure requires the involvement of all staff which plays a key role in active participation and effectiveness of any new implementation of marketing. So future research could focus on university staff perceptions and also on other factors that have impact on perceptions apart from duration of operation, the geographical location and the size of a university.

\section{REFERENCES}

Arora, A. S., \& Sanni, S. A. (2019). Ten Years of 'Social Media Marketing. Journal of Promotion Management, 25(4), 476-499. https://doi.org/10.1080/10496491.2018.1448322

Benavides, L. M. C., Arias, J. A. T., Serna, M. D. A., \& Burgos, D. (2020). Digital Transformation in Higher Education Institutions: A Systematic Literature Review. Sensors, 20(11), 3291. https://doi.org/10.3390/s20113291

Carnegie Dartlet. (2020). Search Engine Optimization for Higher Education. Www.Carnegiedartlet.Com. https://www.carnegiedartlet.com/services/digital-marketing/searchengine-optimization/

Çetin, R. (2004). Planning and Implementing Institutional Image and Promoting Academic Programs in Higher Education. Journal of Marketing for Higher Education, 13(1-2), 57-75. https://doi.org/10.1300/J050v13n01_04

Chaffey, D. (2018). What is Digital Marketing? A Visual Summary. Pridobljeno. https://www.smartinsights.com/digital-marketing-strategy/what-is-digital-marketing/

Downes, L., \& Nunes, P. (2013). Big Bang Disruption. Harvard Business Review, March, 44-56. https://ssrn.com/abstract=2709801

Featherstone, K. (2015). External Conditionality and the Debt Crisis: the 'Troika' and Public Administration Reform in Greece. Journal of European Public Policy, 22(3), 295-314. https://doi.org/10.1080/13501763.2014.955123

Flick, U. (2009). An Introduction to Qualitative Research (Fourth). SAGE Publications.

Gobble, M. M. (2018). Digital Strategy and Digital Transformation. Research-Technology Management, 61(5), 66-71. https://doi.org/10.1080/08956308.2018.1495969

Hallam-Berry, M. (2018). What is Digital Marketing Transformation? Www.Hallaminternet.Com. https://www.hallaminternet.com/digital-marketing-transformation/

Hayes, T. J., Ruschman, D., \& Walker, M. M. (2009). Social Networking as an Admission Tool: A Case Study in Success. Journal of Marketing for Higher Education, 19(2), 109-124. https://doi.org/10.1080/08841240903423042

Iosiphides, T., \& Spyridakis, M. (2006). Qualitative Social Research, Methodological Approaches and Analysis. Kritiki Publications.

Kotler, P., \& Fox, K. F. (2006). Strategic Marketing for Educational Institutions. Prentice Hall.

Kotler, P., \& Lee, N. R. (2006). Marketing in the Public Sector. Pearson Education.

Kreutzer, R. T., \& Land, K.-H. (2013). Digital Darwinism: Branding and Business Models in Jeopardy. Springer.

Kummer, T.-F., \& Schmiedel, T. (2016). Reviewing the Role of Culture in Strategic Information Systems Research: A Call for Prescriptive Theorizing on Culture Management. Communications of the Association for Information Systems, 38(1), 122-144. https://doi.org/10.17705/1CAIS.03805

Lister, M. (2019). 37 Staggering Video Marketing Statistics for 2018. The WordStream, 9(37). https://www.wordstream.com/blog/ws/2017/03/08/video-marketing-statistics

Maringe, F. (2006). University Marketing: Perceptions, practices and prospects in the less developed world. Journal of Marketing for Higher Education, 15(2), 129-153. https://doi.org/10.1300/J050v15n02_06

McAlexander, J. H., Koenig, H. F., \& Schouten, J. W. (2005). Building a University Brand 
Community: The Long-term Impact of Shared Experiences. Journal of Marketing for Higher Education, 14(2), 61-79. https://doi.org/10.1300/J050v14n02_04

Michaluk, G. (2008). The Marketing Director's Role in Business Planning and Corporate Governance. John Wiley \& Sons.

Molesworth, M., Nixon, E., \& Scullion, R. (2009). Having, Being and Higher Education: The Marketisation of the University and the Transformation of the Student into Consumer. Teaching in Higher Education, 14(3), 277-287. https://doi.org/10.1080/13562510902898841

Nguyen, D. (2018). The University in a World of Digital Technologies: Tensions and Challenges. Australasian Marketing Journal, 26(2), 79-82. https://doi.org/10.1016/j.ausmj.2018.05.012

Pelletier, S. G. (1985). Marketing Higher Education. Educational Horizons, 63(2), 54-60. https://www.jstor.org/stable/42926954

Peruta, A., \& Shields, A. B. (2017). Social Media in Higher Education: Understanding How Colleges and Universities Use Facebook. Journal of Marketing for Higher Education, 27(1), 131-143. https://doi.org/10.1080/08841241.2016.1212451

Pricewaterhouse Coopers. (2018). The 2018 Digital University. In Staying Relevant in the Digital Age. https://www.pwc.co.uk/assets/pdf/the-2018-digital-university-staying-relevant-\%0A in-thedigital-age.pdf\%0A

Pringle, J., \& Fritz, S. (2019). The University Brand and Social Media: Using Data Analytics to Assess Brand Authenticity. Journal of Marketing for Higher Education, 19(1), 19-44. https://doi.org/10.1080/08841241.2018.1486345

Rivero, O., \& Theodore, J. (2013). Marketing in Greece: The Reasons of its Underdevelopment. International Business \& Economics Research Journal (IBER), 12(7), 793-798. https://doi.org/10.19030/iber.v12i7.7973

Rof, A., Bikfalvi, A., \& Marquès, P. (2020). Digital Transformation for Business Model Innovation in Higher Education: Overcoming the Tensions. Sustainability, 12(12), 4980. https://doi.org/10.3390/su12124980

Search Engine Land. (2019). What is PPC? Your Complete Guide to PPC (Pay-per-Click) Advertising. https://searchengineland.com/guide/what-is-paid-search

Shailesh, G., \& Priya, V. (2018). Digital Darwinism and Branding: In Context to Educational Institutions-A Conceptual View. International Journal of Business and Management Invention (IJBMI), 7(5), 37-41.

Silverman, D. (2001). Interpreting Qualitative Data: Methods for Analyzing Talk, Text and Interaction, A Guide to the Principles of Qualitative Research (5th ed.). SAGE Publications.

Smith, L. R., \& Cavusgil, S. T. (1984). Marketing Planning for Colleges and Universities. Long Range Planning, 17(6), 104-117. https://doi.org/10.1016/0024-6301(84)90223-1

Straub, R. (2019). World Economic Forum Report. http://www.marketingjournal.org/the-power-ofecosystems-an-interview-with-richard-straub/\%0A

The World University Ranking. (2020). Digital Student Recruitment in the Time of Coronavirus. https://www.timeshighereducation.com/hub/keystone-academic-\%0Asolutions/p/digital-studentrecruitment-time-coronavirus $\% 0 \mathrm{~A}$

Vexler, M. (2019). Driving Digital Transformation with Cultural Change. https://doi.org/10.13140/RG.2.2.18499.55843

Whitehead, F. (2012). Student Recruitment Strategy: Four Universities, Five Key Questions. The Guardian, 13.1 http://www.guardian.co.uk/higher-educationnetwork/blog/2012/nov/13/studentrecruitment-strategy-international -universities\%3E

Zhao, M., Liao, H.-T., \& Sun, S.-P. (2020). An Education Literature Review on Digitization, Digitalization, Datafication, and Digital Transformation. 6th International Conference on Humanities and Social Science Research (ICHSSR), 10-12.

Zulfikar, M. W., Hashim, A. I. bin, Umri, H. U. bin A., \& Dahlan, A. R. A. (2018). A Business Case for Digital Transformation of a Malaysian-Based University. 2018 International Conference on Information and Communication Technology for the Muslim World (ICT4M). https://doi.org/10.1109/ICT4M.2018.00028 